\title{
FATHERHOOD OF JAVANESE LOW-MIDDLE CLASS
}

\author{
M. Wahib Sahie \\ IAIN Ternate, Indonesia \\ wahibmorotai92@gmail.com
}

\begin{abstract}
This study aims to explore the masculine identity of the fatherhood of Javanese men and to understand its psychological dynamics through 'the experience of being a father'. Therefore, the researcher applied hermeneutic-phenomenology study that which is digging beneath the configuration inside and also construct the gender structure. Also, in this study the subject of researchers came from Java residing in Jomblang Karang Bendo and in this study are those who are in the category of low-middle class. The findings in this study explain that fatherhood is constructed through discourse which is a requirement of the engendered fatherhood. Furthermore, fatherhood is a figure needed in the family (wife and children).
\end{abstract}

Keywords; identity; fatherhood of Java man; lower-middle class of social.

Abstrak: Penelitian ini bertujuan untuk mengeksplorasi identitas maskulin pada fatherhood laki-laki Jawa dan untuk memahami dinamikanya melalui 'pengalaman menjadi ayah'. Oleh karena itu, peneliti menerapkan pendekatan hermeneutikafenomenologis yang menggali konfigurasi dari dalam dan juga bagaimana hal tersebut dapat mengonstruksi struktur gender. Dalam penelitian ini, subjek berasal dari Jawa yang menetap di Jomblang Karang Bendo, DIY dan dalam penelitian ini termasuk kategori kelas sosial menengah-ke bawah. Temuan dalam penelitian ini menjelaskan bahwa fatherhood (wacana Ayah) dikonstruksi melalui wacana genderisasi fatherhood. Lebih lanjut, fatherhood merupakan sosok yang dibutuhkan dalam keluarga (istri dan anak).

Kata kunci; identitas, fatherhood laki-laki Jawa, kelas menengah-ke bawah.

Submission Date

Review Date

Publish Date
: December 20, 2019

; February 18, 2020

: June 01, 2020 


\section{Pendahuluan}

Baru-baru ini, para peneliti telah berusaha untuk memperluas konseptualisasi keterlibatan ayah (father involvement) untuk menyertakan lebih luas cara ayah berpartisipasi dalam kehidupan anak-anak mereka (Marsiglio \& Mark, 2000). Di masa lalu, konsepsi penelitian keterlibatan ayah berkisar tentang ayah yang memberikan dukungan keuangan dan kunjungan, kegiatan satu-satunya antara ayah dan anak, atau indikator lain dari kehadiran ayah atau tidaknya di rumah. Lebih lagi, para peneliti tentang topik ini telah mulai mengkonseptualisasikan maskulinitas sebagai sesuatu yang lebih jamak dan bervariasi.

Konstruksi sosial secara umum tentang wacana fatherhood membentuk suatu tatanan nilai yang menyebabkan ayah diharuskan untuk berperan secara ekstra. Mulai dari mencari pekerjaan sampai mendidik anak demi mempererat hubungan berkeluarga dan rumah tangga dengan tujuan untuk menjaga eksistensi seorang ayah.

Peran seorang ayah dan sebagai calon ayah tentu telah menjadi wacana publik, dimana etnis, ras, dan budaya memiliki pengaruh yang sangat signifikan. Wacana tersebut dapat teramati misalnya di negara Amerika dan Prancis bahwa konstruksi sosial ayah secara umum atau wacana publik mengenai apa yang merupakan kerangka kerja ayah dan hukum baik sangat menentukan hubungan ayah dengan anak dan dapat menciptakan tekanan kuat yang direspon oleh seorang ayah (Doucet, 2006; Featherstone, 2009).
Meskipun konstruksi tersebut bervariasi antara waktu, lintas budaya, dan lintas konteks subkultur yang berbeda (Lamb, 1997) ada indikasi bahwa wacana ini terkonvergensi di berbagai negara maju. Kepentingan publik terhadap calon ayah dan ayah-dalam wacana publik, akademis dan sastra populer, budaya visual telah meningkat di Eropa dan Amerika Utara dalam beberapa tahun terakhir. Dalam wacana tersebut merupakan kebijakan yang telah membuat suatu usaha secara eksplisit dan terarah untuk membuat laki-laki menjadi seorang ayah (Hobson, 2002).

Agenda publik ini, yang sering disebut 'ayah baru' (new fatherhood), juga tampaknya mencerminkan perubahan nyata dalam perilaku dalam rumah tangga, terkait dengan perubahan generasi dalam sikap gender dan perubahan sosiodemografi (khususnya, peningkatan partisipasi kerja perempuan). Namun, tingkat perubahan sosial yang sebenarnya mungkin lebih lambat daripada debat publik yang disarankan atau yang menerima.

Sejalan dengan hal di atas, studi terhadap konsep fatherhood terus menyoroti ketegangan antara tekanan kerja dan tekanan rumah, yang membatasi sejauh mana seorang ayah mampu dan bersedia untuk menegosiasikan ulang identitas maskulinitas. Peran seorang ayah di rumah dan di tempat kerja mendapat tekanan persaingan kerja yang tampaknya akan meningkatkan intensifitas bekerja yang dihabiskan di dalam rumah (Gregory \& Milner, 2011).

Pembentukan relasi produksi yang menempatkan ayah sebagai pencari nafkah dalam keluarga membuat semakin 
kehilangan kepercayaan diri. Hal ini menunjukan para ayah semakin merasa tertekan dalam kehidupannya.

Hal tersebut sering diwacanakan dalam penelitian tentang gender, dimana menjadi seorang ayah harus mampu menafkahi keluarga, dan memberi kehidupan yang layak demi tercukupinya kebutuhan fisiologis. Ketakutan tersebut menyebabkan kehilangan momenmomen penting bersama anak.

Produksi yang berlangsung di dalam rumah tangga mengalami restrukturisasi signifikan, sebagian akibat ekspansi produksi kapitalis, dan sebagian lagi karena perubahan-perubahan di dalam negara.

Otoritas fatherhood bisa dilihat sebagai relasi kekuasaan demi pencapaian tujuan. Misalnya sistem pembagian kerja, lakilaki dan perempuan, dan kesamaan tugas baik mengasuh anak, dan menafkahinya dalam membentuk ideologi.

Dalam masyarakat yang patriarkal, pemahaman kita akan otoritas politik sangat dipengaruhi oleh pengalaman dengan posisi ayah dalam keluarga (Ball dan Muhammad, 2010).

Konsep fatherhood merupakan konsep penting dalam pembangunan identitas laki-laki. Sementara ibu adalah pengasuh utama anak-anak, ayah membuat keputusan utama mengenai perawatan kesehatan anak, pendidikan, dan kehidupan sosial. Terlepas dari gambaran tradisional ayah sebagai figur otoritas dan pencari nafkah (Ball \& Muhammad, 2010) dalam penelitian tentang Exploring Fatherhood in Bangladesh, mengamati bahwa banyak ayah terlibat dengan anakanak mereka dalam berbagai situasi dan menyediakan berbagai kebutuhan anakanak, terutama di lingkungan pedesaan.
Penjelasan di atas menjelaskan bahwa penting untuk tidak mengabaikan atau mengecilkan perhatian langsung yang diberikan setiap hari oleh ayah, terutama saat mereka bekerja dengan anak-anak mereka disamping mereka atau berada di dekatnya, seperti yang sering terjadi di daerah pedesaan.

Pengamatan ini menunjukkan bahwa ayah yang sangat mudah cenderung berfokus pada anak yang telah mencapai tonggak perkembangan, seperti tersenyum, merangkak, berjalan, dan berbicara. Begitu anak-anak mulai bersekolah, banyak ayah terlibat dalam kegiatan pendidikan mereka dan membantu mengerjakan pekerjaan rumah. Secara umum, ayah memberi kesempatan kepada anak untuk mengeksplorasi dan menguasai keterampilan di luar rumah. (Ball dan Wahedi, 2010).

Kouneski \& Erickson mengemukakan bahwa peran ayah dipengaruhi oleh berbagai faktor, termasuk karakteristik individu ibu, ayah, dan anak, faktor hubungan antara ibu dan ayah, dan faktor kontekstual.

Penelitian lebih lanjut diperlukan untuk menentukan bagaimana faktorfaktor ini berinteraksi untuk memprediksi keterlibatan ayah dalam konteks keluarga yang unik (Meteyer \& Jenkins; 2010).

Model sumber ekonomi relatif menunjukkan bahwa kontribusi finansial suami dan istri yang lebih setara kepada keluarga adalah perawatan anak yang lebih setara akan dibagi.

Penelitian sebelumnya untuk menguji model ini telah dikembangkan melalui studi besar yang menemukan bahwa seorang ayah yang memberi kontribusi pada proporsi pendapatan keluarga yang 
lebih rendah lebih banyak terlibat dalam aktivitas pengasuhan. Sementara yang lainnya gagal menemukan bahwa kontribusi ekonomi merupakan prediktor signifikan dari keterlibatan ayah (Deutsch et al., 1993).

Penelitian di atas mengklarifikasi bagaimana kontribusi ekonomi relatif dari orangtua memprediksi tingkat keterlibatan pengasuhan anak orang tua serta peningkatan dan penurunan keterlibatan yang relatif dalam konteks keluarga yang berbeda. Berdasarkan penelitian sebelumnya, diperkirakan bahwa pembagian perawatan anak di antara penerimanya, pasangan kelas pekerja akan paling adil bila kontribusi ekonomi relatif laki-laki dan perempuan serupa.

Model struktural, atau permintaanrespons, menunjukkan bahwa semakin besar tuntutan domestik terhadap seorang ayah dan semakin besar kapasitasnya untuk meresponsnya, semakin banyak ayah akan berkontribusi dalam perawatan anak (Coverman, 1985). Misalnya, model ini akan memprediksi bahwa ayah lebih banyak terlibat saat ibu dipekerjakan bekerja penuh waktu atau ketika orang tua bekerja berlawanan bergeser satu sama lain, karena meningkatnya permintaan untuk partisipasi ayah. Dalam pergeseran pekerjaan diprediksi menjadi faktor penting dalam bagaimana pengasuhan anak. Hal ini dapat dilihat dalam konteks keluarga kelas pekerja dimana mereka (orangtua) sebagai pekerja kelas biasa tidak dapat dipekerjakan dalam pembagian waktu pekerjaan. Karena jadwal bekerja di malam hari sudah tentu dapat mempengaruhi pada waktu yang lain.
Kebutuhan atau desain ekonomi, banyak orangtua di keluarga yang memiliki pendatang baru memutuskan untuk bekerja saling berlawanan satu sama lain, seringkali sebagai strategi untuk menghemat uang dalam biaya perawatan anak dengan hanya mengandalkan perawatan orang tua. Dengan demikian, waktu dimana ibu dan ayah dipekerjakan diharapkan menjadi prediktor penting bagi keterlibatan ayah, terutama ketika ibu dan ayah bekerja di seberang pergeseran. Diperkirakan bahwa pasangan yang bekerja di seberang shift akan terlibat dalam pembagian tugas penitipan anak yang lebih merata.

Partisipasi dalam perawatan anak secara keseluruhan, tidak hanya saat memberi makan bayi, saat ibu sedang menyusui. Apalagi, keterlibatan ayah rendah, ibu terus menyusui bayinya (Beitel \& Parke, 1998). Pada pendapatan rendah, keluarga kelas pekerja, ibu tidak hanya cenderung tidak menyusui daripada rekan kelas menengah mereka, tetapi juga cenderung berhenti menyusui saat kembali bekerja. Dengan demikian keterlibatan ayah di kelas pekerja rumah tangga, atau ketika ibu menghentikan keperawatan ayah dapat meningkatkan keterlibatan mereka dari waktu ke waktu sebagai hasilnya.

\section{Fatherhood}

Fatherhood melibatkan konstruksi dan koding budaya seorang laki-laki sebagai ayah yang meliputi hak, tugas, tanggung jawab dan status yang melekat pada ayah serta wacana seputar ayah yang baik dan ayah yang buruk (Hobson \& Morgan, 2002; Lupton \& Barclay, 1997). 
Sementara fathering adalah kinerja seorang ayah dalam perannya dalam keluarga. Konsep ayah ini bisa dilihat sebagai "doing" fatherhood. Jadi, bukan sosok personal ayah yang dikaji, melainkan tindakan agensi si ayah dalam struktur keluarga.

Konsep ini senada dengan istilah culture of fatherhood dan conduct of fatherhood. Culture of fatherhood meliputi norma-norma, nilai-nilai dan kepercayaan bersama yang melingkupi parenting bagi laki-laki. Sedangkan, conduct of fatherhood meliputi tindakan yang dilakukan ayah (La Rossa, 1988).

Fatherhood juga dihalangi oleh suatu ketiadaan perspektif teoritik yang jelas untuk membingkai konseptualisasi fathering sebagai suatu aktivitas dan fatherhood sebagai status karena telah banyak dikaji melalui prespektif. Sehingga pendefenisian fatherhood dalam artian yang baku telah banyak dikaji dan dikonstruksi oleh banyak prespektif, antropologi, psikologi, sosiologi dan prespektif lainnya.

Konstruksi fatherhood tidak pernah memiliki identitas tetap. Fatherhood mengacu pada pembangunan budaya hak ayah, tanggung jawab, dan status serta kriteria diskursif ayah yang baik dan buruk (Gregory dan Milner 2005), fatherhood adalah konstruksi yang terus menerus untuk menundukan atau menaklukan pertanyaan dan perubahan. Ini berubah dengan situasi sosial yang berbeda dan dipengaruhi oleh kendala struktural, seperti nilai tradisional, norma sosial, dan harapan budaya pada ayah (Coltrane dan Parke 1998; Daly 1995; Marsiglio dan Cohan 2000).

Penelitian selanjutnya telah dikemukakan oleh Muhajir Darwin (1999) tentang Maskulinitas: posisi laki-laki dalam masyarakat patriarki bahwa salah satu stereotype maskulinitas yang penting untuk didekonstruksi adalah konsep fatherhood (ke-ayah-an). Susan (1996) menemukan fenomena di masyarakat Barat yang diteliti bagaimana pekerjaan merawat anak dianggap sebagai pekerjaan yang sarat gender, atau yang lebih spesifik lagi sebagai pekerjaan yang sangat feminim.

Merawat anak cenderung dicurigai, bahkan dianggap sebagai perilaku patalogis. Sementara itu Ralph LaRosa menemukan bahwa kecenderungan lakilaki di Barat saat ini untuk lebih memperhatikan perawatan anak, dan menganggap hal demikian sebagai bentuk modernisasi. LaRossa menyebut kecenderungan ini sebagai "masculine domesticity" atau "domestic masculinity" dan dibagian lain disebut sebagai proses "fatherhood evolusion". Proses ini mengarah kepada pembagian kerja di sektor domestik yang lebih seimbang antara lakilaki dan perempuan.

Brod (1987) dalam bukunya The Making of Masculinity juga menggugat kecenderungan mengabaikan fatherhood sebagai stereotipe maskulinitas. Ia menuturkan secara historis bagaimana pada keluarga Barat awal abad ke-19, peranan fatherhood dari suami lebih menonjol dibanding peranan matherhood seorang isteri. Peranan fatherhood dari suami ini kemudian menurun seiring dengan proses industrialisasi.

Brod (1987) mengatakan bahwa dominasi laki-laki di sektor publik adalah merupakan pelarian laki-laki karena mereka megalami marginalisasi di sektor domestik. Lalu dia mempertanyakan secara kritis, kenapa statistik hanya 
menyediakan angka tentang proporsi ibu rumah tangga yang bekerja, tetapi tidak pernah ada angka laki-laki pekerja yang menjalankan fungsi fatherhoodnya.

Uraian di atas ingin menegaskan bahwa stereotype maskulinitas dapat berarti pengembilan peranan yang seimbang dari laki-laki di sektor domestik. Marginalisasi laki-laki di sektor domestik justru harus dilihat sebagai fenomena sosial yang patologis. Rekonstruksi demikian penting untuk menciptakan hubungan laki-laki dan perempuan yang lebih egalitarian.

\section{Konstruksi Fatherhood}

Hubungan gender yang berubah dalam keluarga karena perceraian, dan perubahan dalam pendekatan kebijakan keluarga dan pendekatan orang tua telah membangkitkan peningkatan dalam penelitian keibuan (Gregory \& Milner 2005). Studi penelitian ini tidak hanya berfokus pada efek keterlibatan ayah, tetapi juga mengeksplorasi ayah sebagai pengalaman dan fenomena gender. Terinspirasi oleh studi perempuan, yang bertujuan untuk mendokumentasikan pengalaman perempuan yang telah terbengkalai dalam penelitian disiplin konvensional (Auslander 1997).

Studi tentang laki-laki pada dasarnya ingin melakukan hal yang sama, dengan menyelidiki maskulinitas dan pengalaman laki-laki sebagai makhluk gender dalam konteks hubungan gender yang lebih luas. Studi tentang kebapaan bertujuan untuk mengungkapkan beragam makna yang saling terkait antara maskulinitas ayah dan kedewasaan itu sendiri (Haywood \& Ghaill 2003).

\section{Konfigurasi}

maskulinitas konvensional terus membentuk Fatherhood dalam praktik pengasuhan anak. Ayah terus menjalankan tanggung jawab mereka dengan cara yang berhubungan dengan dominasi maskulinitas, yang berbeda dengan keadaan ibu. Misalnya, para ayah di kelas sosial terlibat dalam aktivitas fisik bersama anak-anak mereka, menekankan kesenangan dan kegembiraan pada bayi dan anak-anak yang lebih muda, dan mempromosikan kemandirian dan pengambilan risiko pada anak yang lebih tua (Doucet 2006; Pruett 2001). Dengan memeriksa sumber daya dan kendala struktural dan diskursif di antara orang kulit putih kelas menengah dalam membangun tanggung jawab dan pengalaman ayah mereka selama dua tahun.

Penelitian Miller (2011) menemukan bahwa fatherhood masih dibangun di seputar peran pencari nafkah. Dari wawancara dengan seorang laki-laki yang lulus pada 1970-an dari sekolah menengah di kota California mengungkapkan bahwa di AS masih memahami fatherhood yang berhubungan dengan pekerjaan, perkawinan, dan kepemilikan rumah. Sebab ketiga aspek fatherhood ini merupakan apa yang dia usulkan sebagai "konsensus pemikiran", yang merupakan konstruksi budaya. Bertujuan untuk menjadi seorang ayah yang berkualitas. Pekerjaan yang dibayar memungkinkan ayah untuk memberi anak mereka kesejahteraan material, keselamatan, dan sekolah; ayah yang sudah menikah kebanyakan menyerahkan anak-anak mereka kepada seorang ibu yang penuh perhatian dengan karakter yang baik dan anugerah yang 
baik. Rumah yang disediakan adalah melindungi anak-anak dari pengaruh buruk dan berfungsi sebagai tempat perlindungan. Dengan kata lain, peran keibuan terus didefinisikan dalam hal penyediaan ekonomi, perlindungan, dan secara emosional sangat dekat terhadap anak-anaknya. Maskulinitas Keluarga masih dibangun terutama dalam kaitannya dengan anak-anak melalui fungsi penyediaan dan perlindungan (Burgess 1997).

\section{Akar Fatherhood dalam Kajian Gender}

Gender merupakan konstruksi sosial (Connell, 2005; Kimmel, 2011; Ruspini, dkk, 2011; Pini dan Pease, 2013; Jackson, 2016). Maskulinitas merupakan konfigurasi yang berada di dalamnya dan turut mengkonstruksi tatanan gender. Oleh karenanya, menjadi laki-laki atau perempuan bukanlah suatu konsep yang melekat begitu saja. Kelindanan antara self dan social bersama-sama membentuk identitas dan relasi gender.

Tema gender berbeda dengan seks (jenis kelamin), yang mana terma seks lebih mengacu kepada aparatus biologis, laki-laki dan perempuan yang terbentuk melalui kromosom, kimiawi, dan organisasi anatomis. Sebaliknya, gender mengacu kepada makna yang disematkan atas perbedaan tersebut pada suatu kultur (Kimmel, 2011).

Menurut Connell (2005), perlu ditambahkan titik fokus pada proses dan relasi bagaimana laki-laki dan perempuan menjalani kehidupan gendernya. Maskulinitas diperluas cakupannya dengan sekaligus mempertimbangkan posisi dalam hubungan gender, praksis bagaimana laki-laki dan perempuan terlibat, serta efek dari praktik gender tersebut terhadap pengalaman ketubuhan, personalitas, dan budaya.

\section{Manhood dan Fatherhood}

Seperti yang telah ditunjukkan, salah satu perkembangan paling signifikan dalam teori gender, yang muncul sebagian besar sebagai konsekuensi kritik feminis, telah menjadi pengakuan akan perbedaan, ambivalensi dan hierarki di dalam dan di sekitar kategori (Connell, 2005; Seidler, 2006). Tapi sementara 'tidak ada satu mode untuk menjadi laki-laki atau menjadi perempuan.

Stereotip budaya feminim dan maskulinitas memperkuat gagasan tentang bagaimana kita seharusnya (Jackson dan Scott, 2002). Sebagai pengakuan atas ketidakstabilan identitas gender dan berbagai cara untuk mengekspresikan maskulinitas dan feminitas, istilah maskulinitas dan femininitas sekarang lebih banyak dikenali dan digunakan. Hal ini telah menyebabkan kepekaan yang lebih besar dalam pemahaman-misalnya, seputar ayah dan maskulinitas keluarga-tetapi juga pengakuan bahwa tidak semua maskulinitas sama-sama persuasif atau dominan atau menjadi ayah dari usaha yang homogen (Morgan, 2002; Ghaill dan Haywood, 2007).

Perdebatan ini harus diingat sebagai pertanyaan seputar 'kesetaraan jender', 'melepaskan jenis kelamin (undoing gender), 'caring' dan 'fatherhoods' dipertimbangkan di sepanjang buku ini saat pengalaman laki-laki terungkap. Yang perlu diingat adalah kehati-hatian feminis terutama berkaitan dengan saat kita mulai mengeksplorasi pengalaman laki-laki dalam apa yang telah didominasi perempuan. Domain kehidupan sosial 
'(Doucet, 2006; Seidler, 2006). Apa kemudian, telah berimplikasi pada pemahaman yang lebih bernuansa maskulin dan gagasan terkait ayah yang baik'. Kedua konfigurasi dan praktik ayah dari ayah modern (Hobson \& Morgan, 2002; Vuori, 2009; Williams, 2008). Seperti yang dicatat oleh Wall dan Arnold, 'melibatkan ayah, terutama anak-anak muda, terus berpadu dengan cita-cita budaya maskulin yang hegemonik. Pada saat yang sama, laki-laki mungkin merasa dikecualikan (atau memang dikecualikan) dari domain yang telah dikaitkan secara intim dengan wanita dan kemampuan 'alami' mereka untuk perawatan.

Konsep di atas menunjukan bawah pada saat yang sama perawatan dianggap undervalued, dianggap mudah (karena itu yang dialami) dan bukan pekerjaan nyata, dan domain ini orang mungkin merasa tidak memiliki keterampilan atau kompetensi alami untuk berpartisipasi secara kompeten atau tepat. Gagasan tersebut lebih terarah dengan latar belakang hubungan kekuasaan dan struktur yang meluas yang berasal dari bentuk maskulin hegemoni, termasuk asumsi esensialis tentang kehidupan perempuan dan laki-laki dan tuntutan ekonomi pasar tenaga kerja (Knijn \& Selten, 2002; Milner, 2011).

\section{Metodologi Penelitian}

Penelitian ini menggunakan pendekatan kualitatif. Langdridge (2007) menegaskan bahwa metode kualitatif merupakan metode yang memusatkan perhatian pada deskripsi atau interpretasi terhadap fenomena melalui pemaknaan terhadap peristiwa dialami oleh manusia. Penyelidikan kualitatif ini memfokuskan pada pengalaman dan makna yang dihayati. Pendekatan ini diapropriasi menimbang tema maskulinitas terkaitsimpul dengan dualitas pengalaman sekaligus struktur realitas sosial yang saling berkaitan dalam praktik kehidupan sehari-hari. Fenomena ini bersesuaian dengan karakteristik penelitian kualitatif yang diajukan oleh Poerwandari (2013), beberapa diantaranya yaitu: mendasarkan diri pada kekuatan naratif; sirkuler; dinamis; peneliti sebagai instrumen kunci. Paradigma yang diadopsi pada penelitian ini adalah fenomenologi. Fenomenologi-sebagaimana yang diterapkan pada penyelidikan psikologisberkaitan dengan upaya memahami secara lebih mendalam kondisi manusia yang termanifestasikan pada kehidupan sehari-hari, konkrit, dan pemaknaan atas pengalaman personal. Tindakan memaknai sudah tentu melibatkan interpretasi (Spinelli 2005; Finlay, 2011; Frost, 2011; Willig, 2013).

Pertimbangan akademis dalam menggunakan pendekatan fenomenologi berakar pada kekhasan fenomenologi dalam penyingkapan pengalaman prareflektif yang tampak pada dunia kehidupan sehari-hari (Husserl, 1967; Zahavi, 2012). Pengalaman pra-reflektif ini merupakan pengalaman yang dihayati oleh partisipan sehari-hari yang bertujuan agar pengalaman sehari-hari itu mengatakan tentang dirinya sendiri. Dengan kata lain, momen pra-reflektif merupakan momen perjumpaan (encountering) manusia dan dunia. Selain pertimbangan tersebut, Willig (2013) menyebutkan bahwa penelitian psikologi kualitatif banyak menerapkan berbagai varian metode yang diderivasi dari 
pendekatan fenomenologi. Pada konteks penelitian, memungkinkan peneliti memilih metodologi penelitian yang bercorak hermeneutika-fenomenologis, khususnya yang dipelopori oleh Paul Ricoeur dan Gadamer (Gadamer, 2004; Ricoeur, 1981; Piercey, 2016). Ricoeur (1981, 1988, 1991, 1992) menegaskan bahwa suatu pengalaman kehidupan dapat berlaku sebagai teks dan naratif yang membentang melalui waktu. Identitas diri merupakan naratif yang terbentang dan terserak melalui temporalitas.

\section{Sampling}

Partisipan pada penelitian ini berjumlah lima orang laki-lakis sebagai Ayah yang dipilih secara purposif (purposive sampling) dengan rentang usia minimal 40-65 tahun. Erikson (2010) mengemukakan bahwa seseorang yang telah memasuki usia dewasa menengah dapat menjalin hubungan atau berinteraksi secara baik dan menyenangkan dengan generasi penerusnya berdasarkan pengalaman yang mereka alami. Yang disebut sebagai generatifity. Penjelasan tersebut, sehingga peneliti memiliki alasan bahwa pada usia ini, subyek peneliti menjadi indkator utama dalam penelitian. Pengerahan partisipan dialamatkan pada laki-laki yang tinggal di Yogyakarta. Studi pendahuluan pada lokasi penelitian mengisyaratkan bahwa beberapa orang Father menyatakan kesediaannya untuk membantu peneliti dalam pengambilan data.

\section{Pendekatan Analisis Naratif (Fenomenologi)}

Hermeneutika-fenomenologis pada konteks penelitian ini dapat digolongkan ke dalam hermeneutika kritis (Busachchi, 2015; Haryatmoko, 2016). Filsafat Ricoeur mendamaikan pertentangan polaritas subjektivitas pada fenomenologi dan objektivitas pada strukturalisme dengan jalan menggunakan kedua kutub pendekatan tersebut. Ricoeur melakukan sintesis terhadap eksplanasi (explanation, erklaren) pada kutub objektivitas dan pemahaman (interpretation, verstehen) pada kutub subjektivitas (Ricoeur, 1991). Hermeneutika-fenomenologis terdiri dari tiga tahap refleksi: analisis struktural (explanation), analisis reflektif (interpretation), dan analisis eksistensial (understanding) (Ghasemi, dkk, 2011).

Tugas interpretasi adalah membantu menguak makna teks, intensi yang tersembunyi di balik teks (Haryatmoko, 2016). Ricoeur (1991) mendefinisikan text is any discourse fixed by writing, teks merupakan wacana yang terpateri dalam tulisan. Oleh karenanya, Ricoeur memberlakukan penyelidikan fenomenologis melalui analisis struktural dan hermeneutika kecurigaan (hermeneutic of suspicion) (Scott-Baumann, 2009) untuk menemukan makna di depan teks melalui distansiasi dan otonomisasi teks. Pada konteks ini, teks tersebut merupakan narasi perjalanan hidup.

Perjalanan hidup merupakan naratif yang direfigurasi pada bingkai-bingkai peristiwa. Bruner (1990) menegaskan bahwa naratif merupakan dasar dari proses penciptaan makna dan satusatunya cara untuk menjelaskan waktu yang dihayati seseorang dalam hidupnya adalah dengan menggunakan bentuk 
naratif. Ricoeur (1984; 1992) mengatakan bahwa naratif melibatkan tatanan peristiwa yang mempunyai kesatuan makna dengan kehidupan yang mewaktu.

Peneliti memilih Analisis Naratif Kritis (Critical Narrative Analysis) dengan pertimbangan bahwa teknik ini cenderung melihat secara kritis pembentukan konstruksi naratif seseorang yang merentang dalam waktu, yang dalam hal ini perjalanan hidup pada tahap-tahap penting menjadi perhatian. Naratif merupakan skema fundamental yang menghubungkan tindakan dan peristiwa individu ke dalam kesatuan yang terintegrasi dan terkontekstualisasi. Naratif merupakan hal penting pada proses pembentukan makna. (Langdridge, 2007; Hiles dan Cermak, 2008; Stainton-Rogers, 2011). Pada konteks maskulinitas Fatherhood, naratif merupakan aspek penting yang perlu disingkapkan pada konstruksi identitas tanpa mengabaikan kompleksitasnya.

Analisis naratif kritis merupakan analisis secara intensif, menggabungkan hermeneutika kecurigaan (hermeneutic of suspicion), pengupasan kembali lapisan makna untuk menilai ulang pemahaman awal. Analisis ini juga melibatkan refleksi kritis terhadap pra-konsepsi peneliti (Stainton-Rogers, 2011).

Langdridge (2007; Stainton-Rogers, 2011) mengemukakan enam langkah -yang lebih dianggap sebagai lingkaran hermeneutik daripada langkah hirarkissebagai berikut:

a. Kritik terhadap ilusi subjektivitas

Tahap ini peneliti membaca transkrip cerita dan refleksi dampaknya terhadap bagaimana peneliti memahami topik yang sedang diteliti. Keterbukaan terhadap teks yang memungkinkan fusion of horizons (Gadamer, 2004) menjadi penting ketika mencoba mengapropriasi makna. Hermeneutika kecurigaan imajinatif beroperasi melalui keterlibatan kritis dengan teori sosial yang tidak menundukkan makna dari partisipan kepada subjektivitas peneliti. Dengan kata lain, posisi subjektif peneliti yang sudah membawa keyakinan dan wawasan mengenai topik penelitian dilibatkan secara kritis melalui teori sosial.

Peneliti mencoba menawarkan cara alternatif dalam melihat, yaitu tidak melulu menyingkap kebenaran tersembunyi yang mengendap di bawah permukaan, melainkan suatu cara yang mengambil posisi alternatif -menyadari bahwa peneliti sudah selalu mempunyai sudut pandang tertentu dalam struktur ideologis- sehingga memungkinkan critical move yang melampaui posisi awal peneliti. Dengan kata lain, peneliti melibatkan perspectival shift untuk memahami dunia-kehidupan, melalui penyelidikan kritis imaji sosial dunia naratif yang dihuni oleh partisipan (Langdridge, 2007).

b. Identifikasi naratif, nada naratif, dan fungsi retorika

Peneliti melakukan standar analisis naratif untuk menemukan aspek cerita yang distingtif dan identifiable dalam teks seperti momen-momen penting -seperti yang diajukan oleh McAdams (Langdridge, 2007), yang meliputi pengalaman puncak, nadir, memori krusial dalam hidup- yang melibatkan setting dan karakter-karakter baru yang mungkin diindentifikasi pada bagianbagian naratif. 
Peneliti juga memperhatikan tone of narrative yang menyajikan makna penting melalui ekspresi dan sikap-sikap tertentu. Nuansa naratif dapat memberikan informasi mengenai hal-hal yang tidak muncul dalam konteks teks pada kisah yang diceritakan oleh partisipan, seperti optimisme/ pesimisme, komik/ tragis, senang/ sedih, bagaimana dan dimana argumen digunakan melalui fungsifungsi retoris yang digunakan untuk menjelaskan, menjustifikasi, maupun mengkritisi (Langdridge, 2007). Hal di atas memungkinkan untuk memunculkan wacana (discourse) yang terbangun melalui aspek-aspek struktural tersebut.

c. Identitas dan kerja identitas

Pada tahap ini peneliti berusaha menyingkapkan konstruksi identitas sebagai sesuatu yang dipertaruhkan (dalam hal ini pengelaman sebagai ayah). Kerja identitas tentang bagaimana seseorang menyajikan tindakan, nilai, dan pendapat dengan cara yang menentukan identitasnya.

Ricoeur (Langdridge, 2007) mengatakan bahwa "a life examined ... is a life narrated". Kehidupan merupakan proses konstruktif yang memungkinkan manusia mencoba untuk menemukan identitas naratif yang turut membentuk kehidupan tersebut. Identitas naratif ini dibawa ke dalam cerita yang dikisahkan oleh partisipan yang diantaranya mencakup "siapa orang yang ini? seperti apa orang pada naratif dan bagaimana hubungannya dengan apa yang sudah diketahui melalui orang ini (usia, etnis, dan profil lainnya)".

Langdridge (2007) menjelaskan bahwa pemisahan tahap ini dan sebelumnya (tahap 2 dan 3) bersifat artifisial. Hanya saja pada tahap ini peneliti memfokuskan diri pada konstruksi identitas naratif yang terbentuk. Tujuan penelitian menjadi panduan agar peneliti tetap concern pada konstruksi identitas maskulin yang menjadi perhatian utama.

d. Prioritas tematik dan hubunganhubungan antar tema

Peneliti melakukan analisis tematik yang diderivasi dari tahap 2 dan 3 . Tahap 2, 3, dan 4 merupakan kerja naratif secara struktural yang dalam hermeneutikafenomenologis Ricoeur merupakan kutub objektivitas (Haryatmoko, 2016) objektivitas dalam tidak dalam pengertian positivistik, melainkan dalam artian analisis tekstual yang bertumpu pada dunia teks.

Pada tahap ini peneliti mengidentifikasi tema dan keterkaitan antara tema dan cerita yang dipaparkan oleh partisipan. Langdridge (2007) menganjurkan bahwa peneliti mengidentifikasi tema-tema mayor pada teks tanpa menghilangkan makna naratif yang dihadirkan. Lebih lanjut, Langdridge (2007) mengatakan bahwa pencarian tema-tema kunci dapat dilakukan secara langsung pada teks naratif dengan cara membuat catatan pada marjin kalimat, frase, dan berbagai ide kunci yang muncul pada naratif.

e. Destabilisasi naratif

Pada tahap ini peneliti terlibat secara langsung dalam kritik politis terhadap teks (a political critique of the text) (Langdridge, 2007). Maksudnya, keterlibatan peneliti -yang sudah selalu secara kultural, sosial, dan politis memiliki perspektif tertentu- dengan imaginative hermeneutic of suspicion melalui teori sosial (Langdridge, 2007), dalam hal 
ini teori-teori maskulinitas sebagai kerja hermeneutis.

Tahap ini menentukan "kerja kecurigaan" dengan perspektif teori sosial pada tema tertentu yang lebih merepresentasikan topik yang diteliti (Stainton-Rogers, 2011). Pada konteks penelitian, sensitivitas pada dimensi maskulinitas lebih ditonjolkan sambil tetap melihat keterkaitannya dengan tema lain yang bisa saja memunculkan wawasan tertentu. Dengan kata lain, peneliti menerapkan hermeneutika kecurigaan-dalam konsep Ricouer disebut dengan distansasi (Ricoeur, 1981)-sebagai fungsi kritik untuk melihat makna yang hadir di depan teks yang relevan dan berkontribusi positif terhadap masa depan isu maskulinitas.

Hermeneutika berbasis gender menjadi alat kritik terhadap wacana yang terkuak pada narasi. Dunia teks menghadirkan wacana yang bisa saja tidak terpikirkan dan tidak dimaksudkan oleh partisipan yang bercerita sendiri. Ricoeur (1981) mengatakan bahwa teks menjadi otonom bila didekati dengan hermeneutika kecurigaan. Hal inilah yang memungkinkan adanya wacana baru yang terkait dengan tatanan sosial yang berlaku pada masyarakat tersebut.

\section{f. Sintesis kritis}

Pada tahap ini, semua tahap sebelumnya dibawa bersama-sama untuk menghasilkan interpretasi secara keseluruhan. Perhatian terhadap potensi untuk melewati prosesnya secara berulang menjadi penting untuk analisis lebih lanjut sampai tidak ada lagi yang perlu ditambahkan (Stainton-Rogers, 2011).
Pada tahap ini menjadi penting untuk menyajikan kembali tema-tema kunci naratif. Pembahasan terhadap nuansa naratif dan fungsi retorik disintesiskan bersamaan dengan identitas naratif. Tema yang menguak serta praktik kerja hermeneutika kecurigaan yang operasional disintesiskan secara mendalam pada tahap ini.

\section{Hasil dan Pembahasan}

Hasil dalam penelitian ini berlangsung di Kampung Jomblang Karang Bendo, Kelurahan Banguntapan, Kecamatan Banguntapan, Kabupaten Bantul Yogyakarta dengan jumlah kepala keluarga kurang lebih 120 kepala rumah tangga. Tempat penelitian tersebut mengantarkan peneliti sehingga dapat mengetahui sejauh mana tinggat kegotongroyong, dan peka antara sesama. Tingkat ekonomi untuk masyarakat kelas bawah menengah dan kelas bawah keatas, di masyarakat Banguntapan relatif rendah. Artinya perbandingan kategori antara kelas bawah dan kelas atas lebih dominannya adalah kelas bawah. Hampir semua dari kelas menengah kebawah memiliki pendapatan ekonomi di bawah rata-rata yang kurang lebih (tiga ratus ribuh sampai empat ratus ribuh rupiah). Menurut warga setempat, kelurahan banguntapan tidak semua adalah warga asli pribumi, sebagiannya adalah warga dari luar yang sudah lama berdomisili dan tinggal di kelurahan Banguntapan. Kelurahan Banguntapan terdapat keaneragaman budaya dan multiagama; islam, hindu, protestan, dan nasrani. Mata pencariaannya lebih banyak melalui usaha-usaha kecil, usaha ketoprak, usaha 
tukang cukur kelapa, dan usaha kecil lainnya. Yang pendapatnya relatif sedikit.

Pelaksanaan penelitian ini berlangsung selama empat bulan antara bulan juli sampai bulan oktober. Dalam penelitian tersebut peneliti memilih subyek yang berada di Kelurahan Banguntapan, Kecamatan Banguntapan, Kabupaten Bantul Yogyakarta. Subyek dalam penelitian ini sebanyak 5 (lima) orang dan subyek dalam penelitian ini adalah laki-laki Jawa sebagai fatherhood. Mereka yang ada dalam kategori lower middle class of social (kelas menengah bawah) sebagaimana dilihat dari latar belakang dan pekerjaannya.

Pembahasan pada penelitian dapat di jelaskan sesuai dengan hasil temuan, dalam penetilian tersebut, di antaranya; laki-laki adalah tanggung jawab, mendidik moral anak, bersama-sama menganggkat tanggung jawab domestik, siap tidak siap menikah wajib dilakukan, bekerja untuk masa depan yang lebih baik dan tidak ada standar baik-buruk. Pada hasil penelitian tersebut menunjukan lakilaki sebagai ayah memiliki komitmen, dan tanggung jawab yang sama antara suami dan istri. Sehingga mereka bekerja secara bersama-sama dengan tujuan menjujung tinggi nilai-nilai keharmonisan.

Laki-laki sebagai ayah adalah penentu kebijakan dalam suatu rumah tangga dan bertanggung jawab menafkahi keluarga (anak dan istri). Hasyim, Kurniawan, dan Hayati (2011) dalam penelitiannya mengemukakan bahwa laki-laki harus mampu bertanggung jawab menafkahi keluarga lahir dan batin pada keluarga, serta memberi jenengan kepada keluarga, artinya seorang laki-laki harus dapat mengangkat harkat dan martabat keluarga serta menjaga nama baik (jeneng
= nama). Peran tersebut; posisi laki-laki sebagai ayah. Dalam penelitian ini, subyek memiliki konsep tentang sosok ayah yang bertanggung jawab. Salah satu pemahaman yang telah terpolarisasi sehingga ayah adalah totalitas (bentuk tanggung jawab). Artinya bahwa ayah bertanggung jawab dalam segala bidang, menafkahi, mendidik anak, dan menjaga keluarga sesuai dengan harapannya. Konsep tanggung jawab dalam berumah tangga laki-laki sebagai ayah dikonstruksi melalui wacana sehingga ayah sebagai laki-laki memiliki standar nilai, berdasarkan kesepakatan-kesepakatan.

Dalam hal mendidik moral anak seorang ayah juga ikut terlibat, mendidik dan menjaga seorang anak. Uraian tentang peran ayah dalam pembentukan moral anak juga dijelaskan oleh Hart (2002; Abdullah, 2010) yaitu; memenuhi kebutuhan finansial anak untuk membeli segala keperluan anak, menjadi teman bagi anak termasuk teman bermain, memberi kasih sayang dan merawat anak, mendidik dan memberi contoh teladan yang baik, mamantau atau mengawasi dan menegakkan aturan disiplin, pelindung dari resiko atau bahaya, membantu, mendampingi, dan membela anak jika mengalami kesulitan atau masalah, dan mendukung potensi untuk keberhasilan anak.

Ibung (2009) mengatakan bahwa kehadiran ayah juga memegang peranan penting dalam pemberian efektifitas teladan terhadap anak-anaknya. Dalam penetian ini subyek sebagai seorang ayah dan anak terlibat secara positif dalam pengasuhan anak. seorang ayah dapat membantu pengasuhan anak dalam segala hal. Yaitu, mendisiplinkan anak, membantu tugas sekolah, terlibat dalam 
persoalan pribadi anak. Seorang ayah memiliki peran yang sama dengan ibu dalam hal mendidik anak.

Untuk bagian tanggung jawab domsetik atara suami dan istri memiliki peran yang sama. Pola hubungan suami istri dalam keluarga adalah laki-laki sebagai penentu kebijakan serta inspirator bagi perkembangan keluarga kedepan, sedangkan istri mempunyai kedudukan sebagai pelaksanaan kebijakan. Dan juga dibutuhkan keharmonisan dalam berumah tangga. Hasyim, Kurniawan, dan Hayati, (2011) menjelaskan hubungan serasi dan harmonis serta dialog antara suami-istri dimaknai sebagai hubungan pengambil kebijakan dan pelaksana kebijakan. Jika pelaksanaan kebijakan mampu melaksanakan segala keputusan dari penentu kebijakan maka rumah tangga dianggap harmonis dari sudut padang laki-laki.

Penelitian tersebut membingkai hubungan relasi tanggung jawab yang harmonis. Dikarenakan suami sangat menjunjung tinggi nilai-nilai kebersamaan dalam keluarga. Subyek dalam penelitian ini mengungkapkan bahwa untuk masyarakat di Jawa tidak ada pola pembagian secara jelas. Istri dan suami lebih banyak bekerja bersama-sama melakukan pekerjaan dalam hal tanggung jawab domestik. Selanjutnya, laki-laki dan perempuan (suami dan istri) dalam hal tanggung jawab (mendidik anak), pada subyek peneliti ayah juga melakukan tanggung jawab yang sama seperti ibu. Peran seperti ini, di dalam kebudayaan masyarakat Jawa tidak menjadi keluhan buat laki-laki. Pendapat tersebut dapat dijelaskan oleh Hasyim, Kurniawan, \& Hayati (2011) mengenai hasil temuan pada beberapa subyek. Mengemukakan bahwa subyek dalam penelitian ini memeliki pandangan bahwa pada dasarnya pengasuhan anak tetap menjadi tanggung jawab bersama antara ayah dan ibu.

Selanjutnya, pada temuan tentang sikap laki-laki saat menikah mengungkapkan pernikahan adalah suatu keniscayaan dan kewajiban (untuk menikah). Artinya sebagai laki-laki sudah pasti akan menginginkan suati pernikahan demi menunjukan identitas sebagai ayah. Namun untuk membentuk suatu ikatan rumah tangga sebagai lakilaki tentu mempersiapkan kesiapan secara mental. Konsep tersebut dapat dijelaskan oleh Blood (1969; Williams, S dan Wahlstrom, C. 2006) menyatakan bahwa kesiapan untuk menikah dapat terbagi ke dalam dua bagian, yakni kesiapan personal dan kesiapan kondisional. Kesiapan personal terdiri dari: kematangan emosional, yang dipengaruhi oleh usia, kematangan sosial, yang berhubungan dengan masa pengalaman sewaktu pacaran, dan kesiapan kondisional, yaitu sumber daya keuangan, dan sumber waktu.

Sedangkan untuk masa depan keluarga adalah suatu harapan yang diimpikan oleh seorang ayah. Seperti kita tahu bersama, secara umum bahwa semua laki-laki bangga ketika menjadi ayah. Semua subyek dalam penelitian ini mengemukakan hal tesebut. Sebab ayah adalah penentu dalam hubungan keluarga. Bekerja mencari nafkah demi memenuhi kebutuhan keluarga. Tanpa ada perasaan keluhan yang dipamerkan dalam suatu wacana melalui kehidupan berkeluarga. Seorang ayah tetap berusaha 
bekerja lebih baik untuk keluarga. Sosok ayah tetap digambarkan sebagai superioritas yang memiliki kedudukan penting dalam berumah tangga. Laki-laki sebagai ayah memiliki peran tanggung jawab yang menentukan nasib keluarga. Ayah digambarkan sebagai agen dalam menentukan struktur-keluarga. Peran ayah dapat dilihat ketika seorang ayah dapat menghasilkan kebutuhan yang diproduksi melalui tanggung jawab yang diemban. Terwujudnya tanggung jawab yang dilakukan oleh ayah, pencari nafka, mendidik anak, serta peran lainnya dapat dilihat melalui habitus seorang ayah sehingga tidak ada standar penilai baikburuk terhadap ayah. Sebab setiap ayah memiliki harapan yang sama, menginginkan yang terbaik buat anak dan istri.

\section{Kesimpulan}

Seperti telah dikemukakan pada bagian sebelumnya bahwa pada konteks penelitian ini, subyek dalam penelitian ini berasal dari klas sosial menengah ke bawah (lower middle class of sosial). Sehingga berangkat dari berbagai penjelasan tersebut di atas, peneliti dapat berkesimpulan bahwa pada hasil penelitian ini menunjukan kepada kita melalui kerangka pikir (kognitif) kaum laki-kali sebagai Ayah, terkait dengan konsep dinamika maskulinitas dalam fatherhood laki-laki Jawa kelas menengah bawah: studi hermeneutikafenomenologi. Sebagai konsekuensi dari struktur pemikiran yang sedemikian rupa tentang konsep maskulinitas di konstruksi melalui wacana dalam membahas isu-isu maskulinitas, sehingga menyebabkan laki-laki sebagai seorang ayah terus mengemban tanggung jawab sebagaimana mestinya. Dengan membedah atau melakukan dekonstruksi dan rekonstruksi terhadap konsep maskulinitas, dan mengkaitkan konstruksi sosial baru tersebut untuk perubahan sosial yang lebih menyeluruh, yaitu proses pelembagaan hubungan sosial yang egalitarian.

Identitas maskulinitas sebagai seorang ayah telah menunjukan konsep pengetahuan baru. Seorang ayah adalah sosok figur yang dibutuhkan dalam keluarga. Sebab seorang ayah adalah penentu kebijakan dalam suatu hubungan rumah tangga yang membingkai segalah aktifitas tanggung jawab untuk memenuhi segala kebutuhan atau keperluan yang diinginkan oleh anak dan istri. Tanggung jawab laki-laki sebagai ayah adalah bentuk totalitas. Artinya segala bentuk rangkaian tanggung jawab yang diemban, mendidik anak, mencari nafkah, membatu istri dan menjaga keutuhan merupakan tanggung jawab yang akan dilakukan demi kepentingan keluarga. Seorang ayah dalam penelitian ini sangat menginginkan keharmonisan, kerukunan dan keadilan di dalam struktur kehidupan berkeluarga.

Membahas konsep laki-laki Jawa menjadi seorang ayah adalah melihat bagaimana peran seorang ayah. Untuk melihat peran seorang ayah dalam penelitian tersebut telah menunjukan bahwa seorang ayah secara langsung juga ikut bertanggung jawab dalam hal urusan domestik. Seorang ayah dan ibu terlibat bekerja bersama-sama. Hal ini telah menunjukan bahwa indentitas laki-laki sebagai Ayah pada penelitian ini seorang ayah sangatlah harmonis dalam berkeluarga. Dalam berumah tangga seorang ayah juga merasa lebih 
mengutamakan nilai-nilai yang diwariskan dari generasi ke generasi, terpatron dalam maskulinitas menjadikan laki-laki yang harus mengarahkan dirinya agar sesuai dengan apa yang telah "digariskan" tersebut. Laki-laki tidak boleh cengeng, menangis, gemulai, dan berbagai ciri yang menggambarkan sifat "kewanitaan" merupakan aturan tidak tertulis yang harus dipatuhinya.

Selanjutnya, pandangan laki-laki mengenai sifat fatherhood (kebapaan) merupakan suatu identitas yang membanggakan dan dibutuhkan dalam berumah tangga. Semua ayah memiliki cara pandang yang berbeda-beda, melalui proses penghayatan yang terinternalisasi dan di aktualisasikan dalam bentuk tindakan. Keterlibatan seorang ayah di dalam rumah tangga tentu dapat diketahui melalui sejauh mana peran yang dieksplorasi untuk kepentingan keluarga demi memenuhi kebutuhan anak dan istri. Konteks tersebut, laki-laki sebagai ayah terus berjuang demi kepentingan keluarga. Saat seorang ayah diperhadapkan dengan begitu banyak beban, eknomi, dan budaya di dalam struktur sosial-kehidupan sudah tentu secara psikis akan dapat mempengaruhinya. Namun pola kehidupan seperti ini jutru akan menunjukan sikap maskulinitasnya untuk menjadi seorang ayah. Dimana seorang ayah akan lebih bertamba dewasa dan piawai dalam bertindak.

\section{Daftar Pustaka}

Auslander, L. (1997). Do Women's Feminist Men's Lesbian and Gay Queer Studies, Gender Studies?
Differences: A Journal of Feminist Cultural Studies, 9 (3).

Beitel, A.H and Parke, R.D. (1998). Involvement in infancy: The role of maternal and paternal atitudes. Journal of Family Psychology, 12 (2), 268288.

Brod, Harry (ed), (1987). “The Making of Masculinities, The New Men's Studies", Boston: Allen \& Unwin.

Burgess, A (1997). Fatherhood Reclaimed: The Making of the Modern Father. London: Vermilion.

Coles, T (2009). Negotiating the field of Masculinity: The production and reproduction of multiple dominant Masculinity: Journal Men and Masculinity 12 (1).

Coltrane, S, and Parke. Ross D. (1998). Reinventing Fatherhood: Toward a Historical Understanding of Continuity and Change in men's Family Lives. Philadelphia, PA: National Center on Fathers and Families.

Connell, R (2009). Gender in World Perspective. $2^{\text {nd }}$ Edition. Cambridge: Polity.

Connell, R. (2005). Masculinities. $\quad 2^{\text {nd }}$ Edition. Cambridge: Polity.

Connell, R. (1995). Masculinity. Cambridge: Polity Press.

Coverman, S (1985). Explaining husbands' participation in domestic labor. Journal Sociology Quarterly, 26, 81-97.

Deutsch, F.M., Lussier, J.B., \& Servis, L.J. (1993). Husbands at home: Predictors of paternal partisipation in childcare and housework. Journal of Personality and Social Psychology, 65.

Dolan, A (2011). "I've Learnt What a Dad Shoul Do: The Interaction of Masculinity and Fathering Indentitas among Men 
Who attended a 'Dads Only' Parenting Programme. SAGE. Journal Sociologi. University of Wawick.

Featherstone, B (2009). Contemporary Fathering. Theory, Policy and Practice. Bristol: Polity Press.

Flood, M. (2002). Between Men and Masculinities: An Assessment of the Term "Masculinity" in Recent Scholarship on Men, dalam Pearce, S. \& Muller, V. (eds). Manning the Next Millennium: Studies in Masculinities. Bentley: Black Swan Press.

Frost, N. (2011). Qualitative Research Methods in Psychology: Combining Core Approach. New York: McGraw-Hill.

Gadamer, H.G. (2004). Truth and Method. Second, Revised Edition. Terjemahan: Wheinsheimer, J. \& Marshall, D.G. London: Continuum.

Gregory, A and Milner, S (2011). What is "new" About Fatherhood. Men and Masculinity. Journal University Of BATH.

Hasyim, N, Kurniawan P, Aditya dan Nur Hayati, E. (2011). Menjadi Laki-Laki (Pandangan laki-laki jawa tentang maskulinitas dan kekerasan dalam rumah tangga). Penerbit Rifka Annisa. Yogyakarta.

Haywood, Chris, and Máirtín Mac an Ghaill. (2003). Men and Masculinities: Theory, Research and Social Practice. Buckingham: Open University Press.

Hobson, B(2002). Introduction. In Making men into fathers. Men, Masculinity and the social politics of fatherhood, 1-21, eds B. Hobson and D. Martin. Cambridge: Cambridge University Press.

Howson, R. (2006). Challenging Hegemonic Masculinity. London: Routledge.

Husserl, E. (1967). Cartesian Meditations: An Introduction to Phenomenology.
Terjemahan: Cairns, D. The Hague: Martinus Nijhoff Publisher.

Ibung, D. (2009). Mengembangkan Nilai Moral Pada Anak. Penerbit Alax Media Komputindo. Jakarta.

Jenkins, R.(2002). Pierre Bourdieu. London: Routledge.

Kimmel, M. \& Messner, M. (2007). "Introduction" dalam Men's Lives. $7^{\text {th }}$ edition. Boston: Allyn and Bacon.

Kimmel, M. S. (2011). The Gendered Society. $3^{\text {rd }}$ Edition. Oxford: Oxford University Press.

Krais, B (2006). Gender, Sociological Theory and Bourdieu's Sociology of Practice. Theory, Culture \& Society 23(6).

Lamb, ME (ed). (1997). The Role of the Father in Child Development. Edition. Chichester: Wiley.

Langdridge, D. (2007). Phenomenological Psychology: Theory, Research and Method. Harlow: Pearson Prentice Hall.

LaRossa, R (1988). The Modernization of Fatherhood: A Social and Political History. Chicago: University of Chicago Press.

Marsiglio, W and Cohan Mark. (2000). Contextualizing Father Involvement and Paternal Influence. Journal Marriage \& Family Review 29(2-3).

Miller, Tina. (2011). Making Sense of Fatherhood, Gender, Caring and Work. Cambridge University Press. New York.

Muzir, Ridwan Inyiak. (2016). Hermeneutika Filosofis Hans-Georg Gadamer. Penerbit AR-RUZZ MEDIA. Yogyakarta.

Poerwandari, E. K. (2013). Pendekatan Kualitatif untuk Penelitian Perilaku 
Manusia. Cetakan kelima. Jakarta: LPSP3 UI.

Ricoeur, P. (1981). Hermeneutics and the

Human Sciences. Terjemahan:

Thompson, J.B. Cambridge:

Cambridge University Press. 